\title{
RETENCIJA PO ORTODONTINIO GYDYMO
}

\author{
Gustė Markevičiūtė ${ }^{1}$, Vilija Berlin ${ }^{1,2}$ \\ ${ }^{1}$ Vilniaus universiteto Medicinos fakulteto Odontologijos institutas, \\ ${ }^{2}$ Vilniaus universiteto ligoninès Žalgirio klinika
}

Raktažodžiai: ortodontinis gydymas, retencija, ortodontiniai reteineriai, nepageidaujamas dantų judejjimas.

\section{Santrauka}

Retencija yra paskutinis ortodontinio gydymo etapas, kurio pagrindinè užduotis - išlaikyti pakoreguotą dantų padètį ir išvengti gydymo recidyvo. Šiam tikslui pasiekti buvo sukurti išimami bei fiksuoti ortodontiniai reteineriai. Išimami reteineriai gali būti dèvimi ne visą laiką ir palengvina burnos higieną, tačiau yra neestetiški ir reikalauja paciento bendradarbiavimo. Fiksuoti reteineriai indikuotini ilgalaikiam dèvejjimui, dažniausiai visam gyvenimui, jų negalima išsiimti. Fiksuoti reteineriai yra estetiškesni ir nereikalauja paciento bendradarbiavimo, tačiau sunkina burnos higieną, gali atsiklijuoti ar lūžti ir sukelti nepageidaujamą dantų judèjimą. Literatūroje nèra bendro atsakymo, kurie reteineriai efektyvesni ar koks jų dèvejjimo režimas optimaliausias. Kai kuriais atvejais taikoma išimamo ir fiksuoto reteinerio kombinacija - dviguba retencija. Šalia reteinerio galima taikyti papildomus retencijos metodus - periciziją ar interproksimalinę emalio redukciją, tačiau tai invazyvios procedūros, todèl jų panaudojimas yra diskutuotinas. Nustačius retencijos režimą, svarbu suplanuoti kontrolinius vizitus retencijos stebėjimui.

\section{Ivadas}

Retencija apibūdinama kaip dantų išlaikymas optimalioje estetinejje ir funkcinèje pozicijoje po ortodontinio gydymo ir yra būtina norint išvengti gydymo metu pasiektos okliuzijos pokyčių [1,2]. E. Angle dar 1907 metais paskelbè, kad po ortodontinio gydymo dantys turi būti prilaikomi savo naujose pozicijose tol, kol visi audiniai, itraukti ị dantų atramą ir palaikymą, bus persitvarkę ir stabilūs [3]. 1959 metais K. Reitan patvirtino, kad ortodontinio gydymo metu ịyksta pokyčiai periodonto audiniuose, todèl, prieš nuimant dantis prilaikantị aparatą, reikia palaukti minkštųjų audinių reorganizacijos ir kaulo remodeliacijos [4].

Retencija po ortodontinio gydymo yra labai svarbi ir gali trukti visą paciento gyvenimą, todèl tiek gydytojams ortodontams, tiek gydytojams odontologams svarbu žinoti ir suprasti ortodontinès retencijos metodikas, trukmę ir kontrolę, naudojamus aparatus ir jų priežiūrą, alternatyvius retencijos būdus [2].

Tyrimo tikslas - apžvelgti mokslinès literatūros duomenis apie retenciją po ortodontinio gydymo. Tyrimo uždaviniai: 1) aptarti ortodontinès retencijos svarbą ir metodus; 2) išsiaiškinti skirtingų reteinerių privalumus bei trūkumus; 3) aptarti papildomus retencijos metodus; 4) apžvelgti literatūros duomenis apie retencijos trukmę ir stebèjimą.

\section{Tyrimo medžiaga ir metodai}

Tyrimo metodas - mokslinès literatūros, nagrinèjančios retenciją po ortodontinio gydymo, apžvalga. Tyrimo šaltiniai: moksliniai straipsniai, elektroninès mokslinių straipsnių duomenų bazès.

\section{Tyrimo rezultatai}

Retencijos po ortodontinio gydymo svarba. Retencija yra paskutinis ortodontinio gydymo etapas, kurio pagrindine užduotis yra išlaikyti dantis pakoreguotose padètyse. Net jei po aktyvaus ortodontinio gydymo bus pasiekta optimali galutinė okliuzija, bet nebus nustatytas retencijos protokolas, galimas gydymo recidyvas [2].

Po ortodontinio gydymo periodonto audiniai turi persitvarkyti pagal naujają dantų padètį. Iki tol, periodonto raiščio skaidulos tempia dantis ị jų buvusią padètį. Ilgiausiai apie 8 ménesius remodeliuojasi elastinès dentogingivalinès ir intradentalinès skaidulos, esančios aplink danties kaklelị, todèl nustatyto retencijos režimo laikymasis šiuo laikotarpiu yra ypač svarbus [5,6]. Jei po ortodontinio gydymo pasiekta okliuzija yra netiksli, tai gali paveikti gydymo rezultatų stabilumą - sąkandžio netikslumai, priešlaikiniai kontaktai bei virškrūvis sukelia dantų paslankumą [2,5]. Nepageidaujamas dantų judèjimas galimas ir dèl normaliu amžiaus pokyčių net tiems pacientams, kuriems nebuvo taikomas ortodontinis gydymas, kadangi su amžiumi keičiasi aplinkinių minkštųjų audinių ir skeletinių 
struktūrų tarpusavio santykis bei spaudimas ị dantis $[2,5,6]$.

Kol kas nèra žinomų būdų kaip nusakyti, ar paciento gydymo rezultatai recidyvuos, ar išliks stabilūs, todèl po gydymo breketų sistema visi pacientai turi dèvèti išimamus arba fiskuotus reteinerius, kurie leidžia išlaikyti dantis naujose pozicijose ir taip sumažina gydymo recidyvo riziką. Reteineriai padeda atsispirti ne tik dantų polinkiui grižti i savo buvusią padèti, bet ir nepageidaujamiems ilgalaikiams amžiniams pokyčiams. Dažnai rekomenduojama ilgalaikẻ retencija, kuri gali trukti visą gyvenimą ir reikalauja paciento bendradarbiavimo $[1,2,5,6]$.

Reteinerių rūšys. Reteinerius galima suskirstyti ị fiksuotus arba išimamus. Pastaruosius pacientai gali išsiimti iš burnos ir netrukdomai išsivalyti dantis. Tokie reteineriai, priklausomai nuo indikacijų, gali būti dèvimi ne visą parą. Fiksuoti reteineriai skiriami norint kuo labiau sumažinti gydymo recidyvo riziką, jie dèvimi 24 val. per parą be galimybès išsiimti iš burnos [2]. Literatūroje nèra bendros nuomonès, kuris retencijos metodas pranašesnis. Skirtingi gydytojai ortodontai renkasi skirtingus reteinerius, priklausomai nuo jų patirties, individualios klinikinès situacijos bei paciento pageidavimų [6].

Išimami reteineriai. Išimamų reteinerių privalumas yra tas, kad juos galima išsiimti valgant ar valantis dantis, todèl pacientams lengviau palaikyti gerą burnos higieną. Priklausomai nuo indikacijų, šiuos reteinerius galima dèvèti ne visą laiką, pavyzdžiui, tik naktimis [5]. Didžiausias išimamų reteinerių trūkumas, tai paciento bendradarbiavimo būtinybé [7]. Jei pacientas nesilaikys gydytojo nustatyto reteinerio dèvèjimo režimo, gali ịvykti ortodontinio gydymo recidyvas. Šiuo atveju atsakomybe dẻl gydymo rezultatų išsaugojimo tenka pacientui [5].

Populiariausi išimami reteineriai yra vakuuminiai arba Hawley tipo. Vakuuminiai reteineriai yra greitai pagaminami ir palyginus nebrangūs. Jie estetiški ir patogūs, todèl pacientų mėgiami $[2,7]$. Vakuuminiai reteineriai gali būti modifikuojami, kad sukeltų minimalius dantų judesius, ị šiuos reteinerius galima istatyti dirbtinius dantis, esant hipodontijai. Rekomenduojama, kad šie reteineriai dengtu visu galiniu dantų okliuzinius paviršius, kad būtų išvengta per didelio krūminių dantų dygimo. Svarbu priminti pacientams išsiimti reteineri geriant ar valgant, ypač jei paciento mityba yra kariesogeniška [2]. Tokio tipo reteineriai populiarūs Jungtinejje Karalystejje, Airijoje bei Malaizijoje [2,6].

Hawley tipo reteineriai yra masyvesni ir patvaresni nei vakuuminiai, todèl jų nebūtina išsiimti valgant. Hawley tipo reteinerių privalumas - sukuriama taisyklinga galinė okliuzija retencijos metu. Tai nèra labai svarbu, jei iki ortodontinio aparato nuemimo buvo sukurta gera galinè interkuspidacija. Šie reteineriai turi lūpinị lanką, kuris gali būti modifikuo- jamas, kad sukeltų paprastus dantų judesius. Prie reteinerio galima prijungti priekinę sukandimo plokštumą, kuri padès išlaikyti gydymo rezultatus po gilaus sąkandžio korekcijos [2]. Dèl masyvumo ir lūpinio lanko šie reteineriai yra mažiau patogūs ir estetiški pacientams [7]. Lietuvoje dažniausiai naudojamas išimamas reteineris yra Hawley tipo [6].

Lyginant Hawley tipo reteinerius su vakuuminiais pastebima, kad pastarieji sukelia mažiau diskomforto ir mažiau paveikia paciento kalbą pirmuosius 6 retencijos mėnesius $[8$, 9], tačiau nèra pakankamai ịrodymų, galinčiu pagristi vieno ar kito išimamo reteinerio klinikinị pranašumą [10]. Vakuuminiai reteineriai gali būti efektyvesni išlaikant pavienių dantų stabilumą po rotacijos, o Hawley tipo reteineriai yra kiek atsparesni, ilgalaikiškesni bei tinkamesni pacientams, kuriu prasta burnos higiena [5,10-12].

Fiksuoti reteineriai. Fiksuoti reteineriai atsirado tik 1970 metais, jų paskirtis buvo užkirsti kelią ortodontinio gydymo recidyvui apatinių kandžių srityje. Šie reteineriai estetiški, patogūs ilgalaikiam dèvèjimui, nereikalingi paciento bendradarbiavimo, kas lemia jų populiarumą $[1,13]$. Fiksuoti reteineriai turi ir trūkumų - jų priklijavimo technika reikalauja tikslumo ir kruopštumo, jie pasižymi trapumu, sunkina dantų išsivalymą, todèl gali sukelti periodonto problemų $[1,5]$.

Fiksuotams reteineriams priskiriamos ịvairaus dizaino vielutès, kompozitu klijuojamos prie priekinių dantų lingvalinio paviršiaus. Dažniausiai naudojamos 0,0215 colių pintos vielutės, priklijuotos prie visų šešių priekinių dantų, arba 0,030-0,032 colių smèliu apdorotos nerūdijančio plieno vielutès, priklijuotos tik prie ilčių [2,13]. A. Andriekutès ir kitų tyrimo apklausos rezultatai parodè, kad Lietuvoje daugiau nei 70 proc. gydytojų ortodontų fiksuotus reteinerius klijuoja prie visų šešių priekinių dantų [6].

Fiksuoti reteineriai yra mažiau matomi, mažiau reikalingi paciento bendradarbiavimo, tačiau pasižymi didesne ilgalaikès nesèkmès rizika [2]. Fiksuoti reteineriai efektyviai išlaiko priekinių dantų padètį daugiau nei 90 proc. atvejų, tačiau kartais gali sukelti nepageidaujamą dantų judejjimą [5, 14]. Ši komplikacija įvyksta, kai vielutè lūžta, tačiau lieka prisiklijavusi prie kelių ar visų dantų, kai vielutè susilanksto arba ne pasyviai priklijuota. Kuo kietesné vielutè, tuo didesnè dantų pajudejjimo rizika, tačiau kuo vielutė minkštesnè, tuo didesnè jos lūžimo rizika $[12,14]$. Paprastai reteinerio nesékmé pastebima per pirmuosius 6 mènesius [1]. Norint padidinti fiksuotų vielučių atsparumą, rekomenduojama jų priklijavimui naudoti kompozitą su daug užpildo dalelių, jas priklijuoti pasyviai, klijavimo metu išvengti užteršimo seilèmis, o dèvint vielutę - nekąsti labai kieto maisto $[1,2]$.

Vienas pagrindinių fiksuotų reteinerių trūkumų - didesnis apnašų ir konkrementų atsidejjimas, lyginant su išimamais reteineriais [2,5]. Tai gali lemti dantenų recesiją, krauja- 
vimą po zondavimo, periodonto ligas, tačiau paprastai nedidina ėduonies išsivystymo rizikos [1]. Klijuojant vielutę, labai svarbu išvengti kompozito kontakto su dantenomis ir tarpdančiais, kad būtų sukurtas kuo patogesnis priejjimas šių sričių išvalymui. Fiksuoti reteineriai paprastai dèvimi visą likusi gyvenimą, todèl labai svarbu išmokyti pacientą tinkamai išsivalyti dantis ir tarpdančius aplink vielutę. Rekomenduojama naudoti tarpdančiu šepetèlius arba „Superfloss"e siūlą [2]. Labai svarbus gydytojo odontologo vaidmuo - kiekvieno vizito metu gydytojas turètu ivvertinti paciento burnos higieną, vielutès ir ją prilaikančio kompozito būklę. Gydytojas odontologas turetų priklijuoti atsilaisvinusią vielutę. Jei vielutė yra ịskilusi, sulūžusi ar visiškai atsiklijavusi, tokị pacientą reikètų siųsti gydytojo ortodonto konsultacijai ir fiksuoto reteinerio pakeitimui $[2,5,12]$.

Fiksuotas ar išimamas reteineris? Fiksuoti reteineriai visada indikuotini šiais atvejais: apatinių kandžių pozicijos išlaikymui vèlyvo augimo metu, diastemos išlaikymui, vietos implantui ar tiltiniam protezui išlaikyti, išrauto danties vietos išlaikymui suaugusiems pacientams [13]. Nors fiksuoti reteineriai siejami su didesniu apnašų kaupimusi, lanksčios vielos reteineriai yra pirmo pasirinkimo pacientams, kurių susilpnejusi periodonto atrama $[10,13,15]$. Apatiniame dantu lanke dažniausiai naudojami fiksuoti reteineriai, kadangi apatiniai kandžiai yra mažiau stabilūs, nei viršutiniai $[12,16]$. Paprastai vielute klijuojama prie visų šešių priekinių dantų - šis klijavimo būdas siejamas su mažesne nesėkmès rizika. Jei paciento burnos higiena prasta, rekomenduojama vielutę klijuoti tik prie ilčių $[1,12]$.

Išimami reteineriai dažnai skiriami viršutinio dantų lanko retencijai, ypač esant mažai gydymo recidyvo rizikai, po dantų pašalinimo ar po dantų lanko plètimo. Išimami reteineriai indikuotini tiek viršutiniame, tiek apatiniame dantų lanke esant prastai burnos higienai arba kai pacientas turi žalingų ịpročių, dèl kurių gali sulaužyti ar atklijuoti fiksuotą vielutę, pavyzdžiui, pieštuko ar nagų kramtymas [12].

Literatūroje aptinkama nedaug įrodymų, kad fiksuoti reteineriai yra reikšmingai pranašesni už išimamus. L. Bahije ir kitų metaanalizejje rašoma, kad fiksuoti reteineriai yra efektyvesni išlaikant kandžių padèti pirmuosius šešis mėnesius, tačiau jų ilgalaikis efektyvumas statistiškai reikšmingai nesiskiria, lyginant su išimamais reteineriais. Fiksuotus reteinerius pacientai vertina geriau, nei išimamus [10].

Dviguba retencija. Kai kurie gydytojai ortodontai skiria dvigubą retenciją - pacientai, turintys fiksuotą vielutę, taip pat turi užsidèti išimamą reteinerị nakčiai. Dviguba retencija indikuotina esant aukštai gydymo recidyvo rizikai. Šio metodo privalumas - jei vielute lūžta ar atsiklijuoja, paciento dantų padètis išlaikoma išimamu reteineriu, kol vielutė pakeičiama $[2,12]$.
A. Andriekutès ir bendraautorių apklausos duomenimis, Lietuvos gydytojai ortodontai dažniausiai rinkosi dvigubą retencijos metodą tiek viršutiniame, tiek apatiniame žandikaulyje, išskyrus atvejus po viršutinio dantų lanko plètimo arba apatinių priekinių dantų rotacijų korekcijos [6].

Papildomi retencijos metodai. Norint dar labiau sumažinti gydymo recidyvo riziką, šalia reteinerių dèvejimo galima atlikti tam tikras minkštujų ir kietujų audinių procedūras.

Pericizija (dar vadinama periferine fibrotomija) yra minkštujų audinių procedūra, kurios metu vietinëje nejautroje nupjaunamos dentogingivalinès ir intradentalinès periodonto skaidulos aplink danties kaklelị. Šios skaidulos tempia dantis atgal $i$ jų buvusią padètí, ypač tuos, kurie prieš gydymą buvo rotuoti [2]. Procedūrą galima atlikti tik tiems pacientams, kurie turi palankų dantenų biotipą ir kortikalinio kaulo atramą, labai nedidelę ar jokios dantenų recesijos bei geba palaikyti nepriekaištingą burnos higieną. Ši procedūra chirurginè, todèl dažniausiai atliekama tik labai rotuotų dantų atvejais [5]. Periferinè fibrotomija, derinama su išimamu reteineriu, gali sukurti reikšmingai geresnę retenciją nei tik išimamas reteineris [10].

Kita papildomos retencijos procedūra yra interproksimalinė emalio redukcija (IPR). Tai kietujų audinių procedūra, kurios metu nušlifuojamas nedidelis emalio kiekis meziodistaliai. Nèra aišku, kodèl ši procedūra sumažina gydymo recidyvo riziką, tačiau manoma, kad tarpdantinių kontaktų suplokštėjimas gretimiems kandžiams suteikia daugiau stabilumo $[2,5]$. Neseniai atliktame tyrime buvo lyginami keli retencijos metodai po I klasės sąkandžio su dantų susigrūdimu ortodontinio gydymo fiksuotais aparatais bei šalinant dantis ir buvo nustatyta, kad interproksimalinè redukcija apatiniame dantų lanke be reteinerio dèvejjimo buvo tiek pat efektyvi mažinant gydymo recidyvo riziką, kaip ir fiksuotas reteineris [17]. Šio tyrimo dalyviai buvo stebimi 5 metus, todèl negalime daryti išvadų apie ilgalaikị IPR efektyvumą, tačiau tai gali būti veiksmingas papildomas retencijos metodas [5].

Retencijos trukmė. Šiuolaikinëje ortodontinejje praktikoje retencijos trukmè stipriai varijuoja. Dėl randomizuotų klinikinių tyrimų, nagrinėjančių skirtingos retencijos trukmès poveiki gydymo rezultatų stabilumui, praktinių ir etinių apribojimų, vis dar nèra ir galbūt nebus priimto galutinio retencijos protokolo. Vienodas retencijos režimas niekada netiks visiems pacientams dèl okliuzijos patologijų įvairovès, skirtingo pacientų skeleto ir minkštujų audinių santykio. Retencijos metodas turi būti pritaikytas kiekvienam pacientui individualiai, siekiant kuo labiau sumažinti gydymo recidyvo riziką [2].

Sutariama, kad svarbiausias retencijos periodas yra pirmieji 12 ménesiu po aktyvaus ortodontinio gydymo. Šiuo laikotarpiu vyksta perdiodonto raiščio skaidulų persitvarky- 
mas $[6,13]$. Kai kuriais atvejais nebeaugančiam pacientui po 12 mènesių retenciją galima nutraukti, tačiau daugelis gydytojų ortodontų net ir išimamus reteinerius skiria ilgesniam laikui [6]. Rašoma, kad išimamus reteinerius pagal indikacijas galima dèvèti visą parą arba dali paros (apie 10 val./ parą). L. Bahije ir kitų metaanalizès duomenimis, retencijos efektyvumas, taikant skirtingus vakuuminio arba Hawley tipo reteinerio dèvėjimo režimus, statistiškai reikšmingai nesiskyrè [10]. Vis dèlto, pirmaisiais mènesiais po aktyvaus ortodontinio gydymo rekomenduojama išimamą reteineri dèvèti kiek įmanoma daugiau. Vèliau reteinerị galima dèvèti tik esant namuose ar tik naktimis [13].

Fiksuotas reteineris dažniausiai priklijuojamas visam gyvenimui arba iki kol pacientas, suprantantis retencijos stokos riziką, nebenori jo dèveti. Išimami reteineriai visam gyvenimui skiriami retai, kadangi bègant laikui paciento bendradarbiavimas yra linkęs mažèti, todèl sunku užtikrinti tinkamą reteinerio dèvèjimą $[13,15]$. Visą gyvenimą trunkanti retencija rekomenduojama po apatinių kandžių susigrūdimo ir rotacijų korekcijos, po generalizuotų tarpų tarp dantų ar diastemos uždarymo bei periodontologiniams pacientams [2].

Retencijos stebėjimas. Net ir pritaikius retencijos protokolą, dantų padètis po gydymo gali pasikeisti. Tai gali įvykti dèl anksčiau išvardintų priežasčiu - periodonto skaidulu persitvarkymo, orofacialinių audinių spaudimo ị dantis, amžinių pokyčių, reteinerio lūžimo, atsiklijavimo ar paciento nebendradarbiavimo ir režimo nesilaikymo, todèl baigus aktyvų ortodontinị gydymą, svarbu suplanuoti profilaktinius vizitus $[2,5,12]$.

Pirmaisiais mènesiais po ortodontinio gydymo būna padidèjęs dantų paslankumas ir didesnè reteinerio nesėkmès rizika, todèl pirmasis profilaktinis patikrinimas turètų įvykti per tris ménesius po ortodontinio aparato nuėmimo ir retencijos režimo paskyrimo. Šio vizito metu tikrinama fiksuoto reteinerio kokybė arba išimamo reteinerio dèvejjimas. Jei pirmojo apsilankymo metu jokių problemų neaptinkama, kitą kontrolinį vizitą galima skirti po šiek tiek daugiau laiko. Per pirmus metus rekomenduojama pacientą patikrinti du arba tris kartus. Vëliau profilaktiniai tikrinimai turètų vykti kasmet. Pastaruoju metu vis dažniau skiriama retencija visam gyvenimui, todèl kasmetiniam retencijos ir bendrosios dantų būklès patikrinimui rekomenduojama pacientą siųsti gydytojui odontologui [12].

\section{Išvados}

1. Net jei po aktyvaus ortodontinio gydymo bus pasiekta optimali galutinè okliuzija, bet nebus nustatytas retencijos protokolas, galimas gydymo recidyvas. Retencijai po ortodontinio gydymo užtikrinti naudojamas išimamas arba fiksuotas reteineris.
2. Išimamas reteineris leidžia palaikyti geresnę burnos higieną ir yra indikuotinas viršutiniame dantų lanke, esant mažai gydymo recidyvo rizikai, tačiau reikalauja paciento bendradarbiavimo. Fiksuotas reteineris yra patogesnis ir dažniau naudojamas ilgalaikiam apatinio dantų lanko stabilizavimui, tačiau lemia didesni apnašų atsidejjimą ir gali sukelti nepageidaujamą dantų judejjimą, reteineriui atsiklijavus ar lūžus.

3. Šalia reteinerių galima taikyti periferinę fibrotomiją arba interproksimalinę emalio redukciją, tačiau tai yra invazyvios procedūros, indikuotinos tik tam tikrais atvejais.

4. Pirmuosius 12 mènesių po aktyvaus ortodontinio gydymo retencija yra būtina, tačiau nèra bendros nuomonès, koks po to turètų būti taikomas retencijos režimas. Pirmaisiais metais po ortodontinio gydymo pacientas turètų atvykti 2-3 kartus profilaktiniam patikrinimui pas gydytoją ortodontą, véliau kasmet apsilankyti pas gydytoją odontologą retencijos ir bendrosios dantų būklès patikrinimui.

\section{Literatūra}

1. Kartal Y, Kaya B. Fixed orthodontic retainers: a review. Turk J Orthod 2019;32(2):110-114.

https://doi.org/10.5152/TurkJOrthod.2019.18080

2. Johnston C, Littlewood S. Retention in orthodontics. Br Dent J 2015;218: 119-122.

https://doi.org/10.1038/sj.bdj.2015.47

3. Angle EH. Treatment of malocclusion of the teeth (7th ed). S.S. White Dental Manufacturing Company, Philadelphia 1907:628.

4. Reitan K. Tissue rearrangement during retention of orthodontically rotated teeth. Angle Orthod 1959;29:105-113.

5. Littlewood SJ, Kandasamy S, Huang G. Retention and relapse in clinical practice. Australian Dental Journal 2017;62(Suppl1):51-57.

https://doi.org/10.1111/adj.12475

6. Andriekute A, Vasiliauskas A, Sidlauskas A. A survey of protocols and trends in orthodontic retention. Prog Orthod 2017;18(1):31.

https://doi.org/10.1186/s40510-017-0185-x

7. Saleh M, Hajeer MY, Muessig D. Acceptability comparison between Hawley retainers and vacuum-formed retainers in orthodontic adult patients: a single-centre, randomized controlled trial. Eur J Orthod 2017;39(4):453-461.

https://doi.org/10.1093/ejo/cjx024

8. Madurantakam P, Kumar S. Fixed and removable orthodontic retainers and periodontal health. Evid Based Dent 2017;18:103104.

https://doi.org/10.1038/sj.ebd.6401267

9. Alassiry AM. Orthodontic retainers: a contemporary overview. J Contemp Dent Pract 2019;20(7):857-862.

https://doi.org/10.5005/jp-journals-10024-2611 
10. Bahije L, Ennaji A, Benyahia H, Zaoui F. A systematic review of orthodontic retention systems: the verdict. Int Orthod 2018;16(3):409-424.

https://doi.org/10.1016/j.ortho.2018.06.023

11. Jin C, Bennani F, Gray A, Farella M, Mei L. Survival analysis of orthodontic retainers, European Journal of Orthodontics 2018;40(5):531-536. https://doi.org/10.1093/ejo/cjx100

12. Wouters C, Lamberts TA, Kuijpers-Jagtman AM, Renkema AM. Development of a clinical practice guideline for orthodontic retention. Orthod Craniofac Res 2019;22(2):69-80.

https://doi.org/10.1111/ocr. 12302

13. Rossouw PE, Malik S. The retention protocol. Semin Orthod 2017; 23:237- 248 .

https://doi.org/10.1053/j.sodo.2016.12.011

14. Shaughnessy TG, Proffit WR, Samara SA. Inadvertent tooth movement with fixed lingual retainers. Am J Orthod Dentofacial Orthop 2016;149(2):277-286.

https://doi.org/10.1016/j.ajodo.2015.10.015

15. Al-Moghrabi D, Pandis N, Fleming PS. The effects of fixed and removable orthodontic retainers: a systematic review. Prog Orthod 2016;17(1):24.

https://doi.org/10.1186/s40510-016-0137-x

16. Swidi AJ, Griffin AE, Buschang PH. Mandibular alignment changes after full-fixed orthodontic treatment: a systematic review and meta-analysis. European Journal of Orthodontics 2019;41(6):609-621.

https://doi.org/10.1093/ejo/cjz004

17. Tynelius GE, Petrén S, Bondemark L, Lilja-Karlander E. Five-year postretention outcomes of three retention methods - a randomized controlled trial. Eur J Orthod 2015;37(4):345-353. https://doi.org/10.1093/ejo/cju063

\section{RETENTION AFTER ORTHODONTIC TREATMENT}

\section{G. Markevičiūtė, V. Berlin}

Keywords: orthodontic treatment, retention, orthodontic retainers, inadvertent tooth movement.

Summary

Retention is the last stage of orthodontic treatment, the main task of which is to keep the teeth in the adjusted positions and to prevent relapse. To achieve this goal, removable and fixed orthodontic retainers were introduced. Removable retainers may be worn part-time and make it easier to maintain oral hygiene, but are unaesthetic and require patient cooperation. Fixed retainers are indicated for long-term or indefinite retention and cannot be removed. Fixed retainers are more aesthetic and do not require patient cooperation, but complicate oral hygiene, are prone to debonding or breaking, and thus can cause inadvertent tooth movement. There is no consensus in the literature as to which retainers are most effective or what retention protocol is most optimal. In some cases, a combination of removable and fixed retainer is used (double retention). In addition to the retainer, adjunctive retention methods such as pericision or interproximal enamel reduction can be used, but these are invasive procedures and their use is debatable. Once the retention protocol is established, it is important to schedule follow-up visits.

Correspondence to: gustemark@gmail.com

Gauta 2021-03-10 